\title{
Digitalization of the Regional Economy: Problems and Prospects
}

\author{
Natalya Mashkina \\ Department of Finance and Credit, SWSU, \\ Kursk, Russia \\ t.natusia@yandex.ru \\ Elena Belyaeva \\ Department of Finance and Credit, SWSU, \\ Kursk, Russia \\ belena2107@yandex.ru
}

\author{
Olga Belyaeva \\ Department of Finance and Credit, SWSU, \\ Kursk, Russia \\ bels21973@yandex.ru \\ Tatyana Polyakova \\ Department of Finance and Credit, SWSU, \\ Kursk, Russia \\ halfjack@list.ruNatalya Solovjeva
}

\begin{abstract}
Digitalization of the economy is the widespread introduction of digital technologies into the economy. This phenomenon is caused by the rapid development of information technology, microelectronics and communications in most countries of the world. The digitalization of the economy is a global process. Development of advanced manufacturing technologies, end-to-end information technologies, neurotechnologies, the internet of things and artificial intelligence. Russian experience in the development and implementation of digital technologies both at the federal and regional levels has been studied very little. As a result, the Russian features of the development of the digital economy, the systematization of existing approaches and their institutional adaptation to their application in Russian conditions are of high scientific and practical interest. The relevance of the research topic is due to the rapidly developing new information and communication technologies in all areas of modern life. The aim of the study, the results of which are presented in this article, is to study the problems and prospects for the development of the regional digital economy. The transfer of the economy to a new level of development is one of the central places at the federal and regional levels. The article considers the main programs for digitalization of the economy in the Kursk region. Also, recommendations were developed to increase the level of development of the digital economy in Russian regions.
\end{abstract}

Keywords-digitalization, digital economy, digital platform, information technology, government program.

\section{INTRODUCTION}

The country's main priority area is the digital economy. The prerequisites for the creation of the digital economy in Russia were the rapid penetration of information technologies into all spheres of human life, a high level of human development, as well as a powerful breakthrough in the development of exact and natural sciences [1].

At the present stage of development of the Russian Federation, issues of economic and financial security of the regions are becoming a priority. The development of the digital economy is the main and one of the most significant trends in the modern world. In Russia, the term "digital economy" received an official state definition in 2017, which was reflected in the Strategy for the Development of the country's Information Society. First of all, the digital economy is viewed from the point of view of creating new markets based on the use of ICT, which will enhance the growth of the Russian economy based on high-tech industries and production facilities.

The digital economy, as defined by the World Bank, is a system of economic, social and cultural relations, its formation is also a matter of national security, competition of domestic companies, and the country's position on the world stage. The main prerequisites for the development of the digital economy were the development of users and the physical infrastructure of the Internet, the IT industry, and the creation of a national e-government system [2].

The advantages of the digital economy in the modern world are:

\section{Optimization of production.}

2. Increase in labor productivity. The human factor, namely, state of health, low motivation of employees, fatigue, no longer affects labor productivity.

3. Availability in production management. Now it is possible to monitor production, as well as keep in touch with the enterprise through digitalization.

4. Instant global movement of goods via the Internet.

5. Reducing threats to national security.

6. Low resource costs for the production of goods [3-4].

In Russia, ensuring the accelerated introduction of digital technologies in the economy and social sphere is one of the national development goals (Presidential Executive Order No. 204 dated May 7, 2018 On National Goals and Strategic Objectives of the Russian Federation through to 2024, hereinafter - Order No. 204). For this purpose, Order No. 204 defines the following tasks:

- increase in internal costs for the development of the digital economy from all sources (as a share in the gross domestic product) by at least 3 times compared to 2017; 
- creation of a stable and secure information and telecommunications infrastructure for high-speed transmission, processing and storage of large amounts of data, accessible to all organizations and households;

- the use of mainly domestic software by state bodies, local authorities.

Digital technologies are used to modernize all sectors of the national economy, opening up new opportunities for doing business and public administration. This forms a new economic space, which provides an opportunity to create and sell competitive products, provide high-quality services and make effective management decisions [5-6].

The main goal of the national digital economy is to create new opportunities for the development, modernization and optimization of all links of economic activity based on digital infrastructure. However, this will not be achieved if there is no progress in digitalization of all regions of the country [79].

However, there are certain problems in the development of digitalization of regions. Among the main ones, we will single out the following: insufficient financing of IT projects in the regions, personnel shortage, inconsistency of actions between different levels of government. In addition, there is a problem associated with the lack or weak development of regional information and telecommunications infrastructure in remote and sparsely populated regions [10].

Consequently, at present, the study of various aspects of the digital economy and the processes of its formation in the regions of Russia is an urgent scientific and practical task.

\section{METHODS}

The main current problem in Russia is weak technical development and weak rates of "digitalization" of the economy; the state needs to stimulate and direct the development of the digital economy.

Restraining factors in development are the low level of technology development and underdeveloped digital infrastructure, which, as a result, leads to ineffective use of production factors, low levels of productivity and competitiveness.

In addition, there is a problem with a decrease in the number of jobs of low and medium qualifications, since jobs will be the most technologically advanced and robotic, which will lead to a decrease in the need for human labor [11].

Further, the level of data security will decrease, since it will be located in the Internet space, and it will need to be protected in certain ways.

The implementation of the Digital Economy of the Russian Federation Program contributes to the creation of a state platform that allows creating a fundamentally new scheme of relations between business, government and the scientific community to increase the country's competitiveness at the global level.

According to the Council for Strategic Development and National Projects under the President of Russia, the total expenditures of the Digital Economy of the Russian Federation Program for the period 2018-2024 will amount to 1.634 trillion rubles. 1.1 trillion rubles of this amount will have to be allocated by the Federal budget, and 534 million rubles - by extra-budgetary resources. 403 billion rubles were allocated for the implementation of the Digital Economy Program in 2019-2021, of which 108 billion rubles should be spent in 2019, 123 billion rubles in 2020, and about 172 billion rubles in 2021. For the implementation of the national program "Digital Economy" in 2019-2021. allocated 403 billion rubles, of which 108 billion rubles. should be spent in 2019, in 2020 - 123 billion rubles, and in 2021 about 172 billion rubles.

In accordance with the Program, in 2018-2019, the foundation for building the country's digital economy was provided, without which the transformation will remain in a state of stagnation.

However, our country lags behind the leaders in the development of the digital economy in many indicators - the level of digitalization, the share of the digital economy in GDP (Fig. 1).

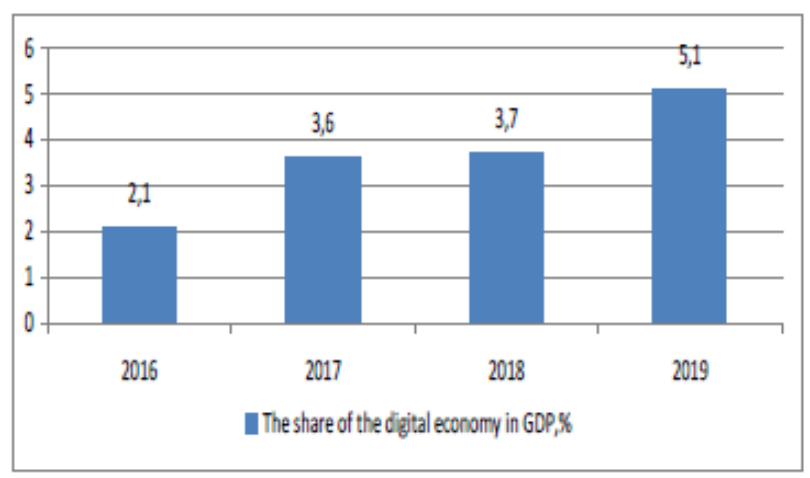

Fig. 1. The share of the digital economy in Russia's GDP for 2016-2019, in percent

Thus, its share in GDP in 2016 was $2.1 \%$. The contribution of the digital economy to GDP from 2016 to 2019 increased by more than 2 times and reached $5.1 \%$ [12].

According to researchers, the potential contribution from the digitalization of the Russian economy will increase the country's GDP by 4.1-8.9 trillion rubles by 2025. (in 2015 prices), which will be from 19 to $34 \%$ of the total expected GDP growth.

Such bold economic forecasts are associated not only with the effect of the automation of existing processes, but also with the introduction of fundamentally new, breakthrough business models and technologies. These include digital platforms, digital ecosystems, in-depth analytics of big data, Industry 4.0 technologies such as $3 \mathrm{D}$ printing, robotization, and the Internet of Things.

The gross domestic spending on the development of the digital economy in Russia reached $3.7 \%$ of the country's GDP. In 2018, their volume reached 3.8 trillion rubles $(+14 \%$ compared to 2017). Organizations spend 2 trillion rubles $(51.5 \%)$ on creating, distributing and using digital technologies and related products and services. More than a third of them $(36.4 \%)$ are household expenditures. Organizations and households spend $11.7 \%$ on purchasing digital content [12].

The main indicator of the development of the digital economy is the provision of universally accessible connections to high-performance broadband Internet networks. 
Russia is the largest country in Europe in terms of the number of Internet users. In 2019 the number of Internet users in Russia amounted to 94.4 million people, the share of Internet users - $79.8 \%$ (Fig. 2).

The structure of Russian Internet users is dominated by women, whose share in the total number of Internet users is $52.5 \%$. The age structure has a high level of Internet penetration in the group of 16-29 years old (97.0\%) and 30-54 years old $(82.0 \%)$. The smallest group consists of people over 55 years old $(28.0 \%)$ [13].

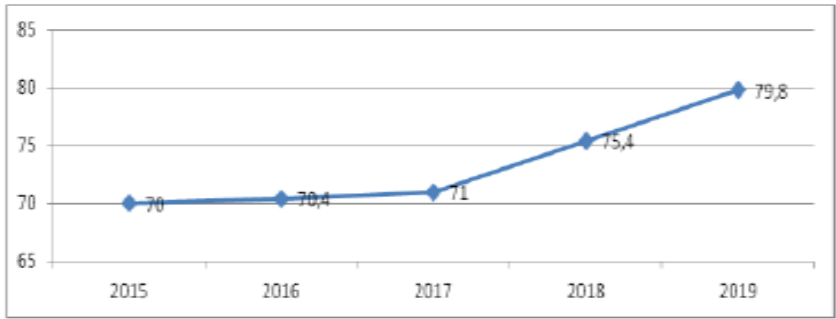

Fig. 2. The share of Internet users in Russia in the total population, in percent

Currently, positive aspects of digitalization are already visible, the Public Services mobile application has won the sixth annual international Best m-Government Service Award in the "Accessible Government" nomination, and this portal is also one of the three most visited public resources in the world [14-15].

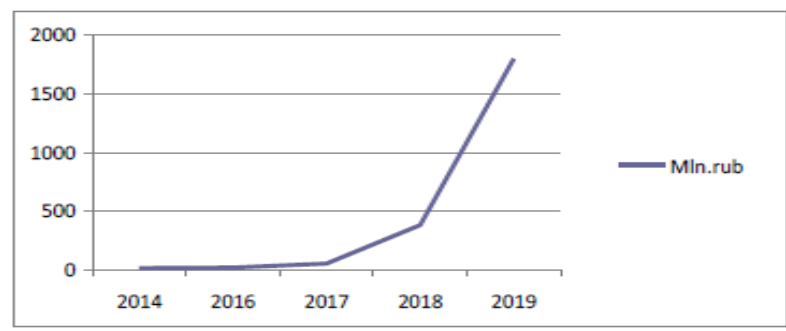

Fig. 3. The number of public services ordered through the Unified Public Services Portal in 2014-2019

Based on this diagram, you can see that the number of public services in 2019 (1.3 billion services) compared to 2014 (7.1 million services) shows an impressive growth of more than 180 times.

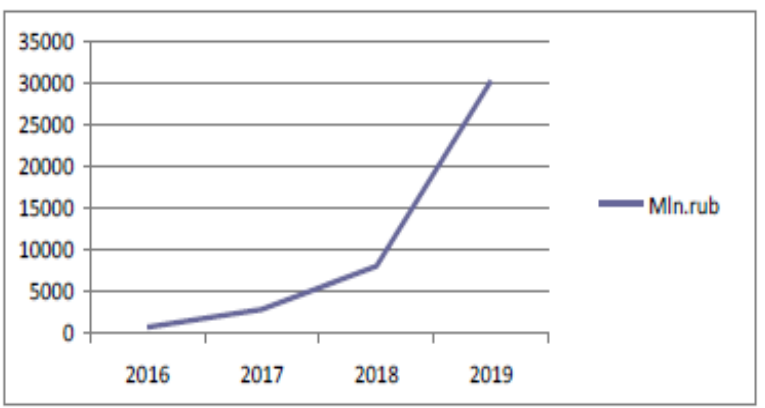

Fig. 4. The volume of payments made by the portal users in 2016-2019 in Russia, million rubles

To achieve the goals of the digitalization program of the Russian Federation, a special assessment toolkit is required, which could allow measuring the effectiveness of measures implemented by the state, identifying problems that hinder the development of digital technologies, adjusting the current strategy and determining priority areas of state support in the field of digital transformation. One of these mechanisms can be an index for assessing the digital maturity of regions of the Russian Federation, because the state policy and digital transformation program should take into account the peculiarities of socio-economic, technological, innovative development and the current level of digitalization and the needs for the development of digital technologies in the regional context.

The level of digital maturity of different countries and regions is assessed on the basis of special indices, while there is no single approach to assessment, the most common assessment methods and their features, which are presented in Table 1 [16].

TABLE I. Comparative analysis of indices for assessing digital maturity of countries and regions

\begin{tabular}{|c|c|c|}
\hline Name & Description & $\begin{array}{l}\text { Russia' } \\
s \text { place } \\
\text { in the } \\
\text { rating }\end{array}$ \\
\hline \begin{tabular}{l}
\multicolumn{1}{c}{ Information } \\
and \\
Communication \\
Technology \\
Development \\
Index (ICT \\
Development \\
Index - IDI)
\end{tabular} & $\begin{array}{l}\text { IDI is based on three sub-indices, } \\
\text { each of which combines its own set of } \\
\text { indicators that characterize a separate } \\
\text { group of processes: ICT access, ICT } \\
\text { usage, and ICT sk0ills }\end{array}$ & 45 \\
\hline $\begin{array}{l}\text { Digital } \\
\text { Economy and } \\
\text { Society Index - } \\
\text { DESI }\end{array}$ & \begin{tabular}{l}
\multicolumn{2}{c}{ DESI is calculated as a composite } \\
index that summarizes various \\
indicators of digital development: \\
connectivity, human capital, the \\
population's Internet usage, business \\
integration with digital technologies, \\
and digital public services
\end{tabular} & 37 \\
\hline $\begin{array}{l}\quad \text { IMD World } \\
\text { Digital } \\
\text { Competiveness } \\
\text { Index — WDCI }\end{array}$ & $\begin{array}{l}\text { WDCI is based on } 50 \text { criteria that } \\
\text { are aggregated into three sub-indices: } \\
\text { knowledge (talent, education, science), } \\
\text { technology (regulation, capital, level of } \\
\text { communication development, export), } \\
\text { readiness (adaptation, business } \\
\text { flexibility, IT integration of business) }\end{array}$ & 40 \\
\hline \begin{tabular}{l}
\multicolumn{1}{c}{ Digital } \\
Evolution \\
Index - DEI
\end{tabular} & $\begin{array}{l}\text { DEI is calculated on the basis of } \\
170 \text { indicators that characterize the } \\
\text { pace of digitalization and are grouped } \\
\text { into four sub-indices: the level of } \\
\text { supply, demand for digital } \\
\text { technologies, the institutional } \\
\text { environment, and the innovation } \\
\text { climate }\end{array}$ & 39 \\
\hline $\begin{array}{l}\text { Index of } \\
\text { Digitalization of } \\
\text { the Economy } \\
\text { Boston } \\
\text { Consulting Group } \\
\text { (e-Intensity) }\end{array}$ & $\begin{array}{l}\text { The e-Intensity index is evaluated } \\
\text { by } 28 \text { indicators, which is calculated as } \\
\text { the weighted average sum of three sub- } \\
\text { indices: infrastructure development, } \\
\text { online spending, and user activity }\end{array}$ & 39 \\
\hline $\begin{array}{l}\quad \text { Networked } \\
\text { Readiness } \\
\text { Index - NRI }\end{array}$ & $\begin{array}{l}\text { The NRI is an assessment of a } \\
\text { country's ability to use the capabilities } \\
\text { of ICT for networking purposes }\end{array}$ & 41 \\
\hline \begin{tabular}{lr}
\multicolumn{1}{c}{ The UN } \\
Global & E- \\
Government & \\
Development & \\
Index - EGDI
\end{tabular} & $\begin{array}{l}\text { EGDI is a composite index that } \\
\text { measures the willingness and ability of } \\
\text { national governments to use ICTs to } \\
\text { organize and deliver public services to } \\
\text { the public and businesses. It is based on } \\
\text { monitoring the technical features and } \\
\text { content of the national websites of all } \\
193 \text { UN member states }\end{array}$ & 35 \\
\hline
\end{tabular}




\begin{tabular}{|c|l|c|}
\hline $\begin{array}{c}\text { E- } \\
\text { Participation } \\
\text { Index - EPART }\end{array}$ & $\begin{array}{l}\text { EPART - indicator of the } \\
\text { development of active communication } \\
\text { services between citizens and the state }\end{array}$ & 32 \\
\hline $\begin{array}{l}\text { Global } \\
\text { Innnectivity }\end{array}$ & $\begin{array}{l}\text { GCI analyzes 40 indicators based } \\
\text { on four sub-indices - supply, demand, } \\
\text { experience and capacity, taking into } \\
\text { account 5 advanced technologies: } \\
\text { broadband networks, data centers }\end{array}$ & 26 \\
\hline $\begin{array}{l}\text { Innovation Global } \\
\text { Index - GII }\end{array}$ & $\begin{array}{l}\text { GII is made up of 82 different } \\
\text { variables that describe in detail the } \\
\text { innovative development of countries } \\
\text { around the world at different levels of } \\
\text { economic development. The index is } \\
\text { calculated as a weighted sum of } \\
\text { estimates of two groups of indicators: } \\
\text { available resources and conditions for } \\
\text { innovation and achieved practical } \\
\text { results of innovation }\end{array}$ & \\
\hline
\end{tabular}

International indexes do not take into account the national characteristics of the country, some of them are based on surveys rather than official statistics, so the Russian Federation is developing its own digital maturity assessment indexes.

The National Digital Economy Development Index will not only assess the digital maturity of Russian regions, but will also help to identify and give recommendations on overcoming barriers to the digital transformation of the Russian Federation in the regional context, among which are already particularly distinguished: insufficient financing of digitalization processes both at the federal level and regional levels; digital divide; low digital literacy level, lack of educational programs and disciplines in new professions, such as a blockchain specialist; lack of exchange of experience and best practices, generalization of regional digital projects; lack of initiative and motivation among domestic companies; different degree of coverage of "digital" achievements in the mass media and, as a result, low awareness of the population about digital services; regulatory rigidity of some laws and lack of regulation in some areas, for example, the crypto industry [17].

The development and application of a special national index for assessing the digital maturity of Russian regions is an important task, the solution of which will help to identify territorial imbalances in the digital transformation process, barriers and drivers on the way to the development of the digital economy of the Russian Federation, to implement a set of measures to overcome the identified problems, to develop state regional digital programs and projects of socio-economic policy and development strategy of the constituent entities of the Russian Federation [18-20].

The most expedient approach for modern Russia is to build a number of industrial platforms (transport, energy, telecommunications, data processing) with a unified structure, which will allow to build a unified digital space in the future [21-22].
TABLE II. The advantages and disadvantages of building industrial platforms in Russia

\begin{tabular}{|c|c|}
\hline Advantages & Disadvantages \\
\hline $\begin{array}{l}\text { Accelerated } \\
\text { formation }\end{array}$ & \multirow{2}{*}{$\begin{array}{l}\text { High risk of } \\
\text { "digital } \\
\text { monopolization" of } \\
\text { industries }\end{array}$} \\
\hline $\begin{array}{l}\text { Maximum transparency and } \\
\text { manageability of systems }\end{array}$ & \\
\hline $\begin{array}{l}\text { Ease of maintenance, } \\
\text { development and integration of } \\
\text { these platforms }\end{array}$ & \multirow[t]{2}{*}{$\begin{array}{lr}\text { High risk of } \\
\text { increasing } \\
\text { inequality }\end{array}$} \\
\hline It should meet the requirements & \\
\hline
\end{tabular}

Industrial platforms serve as an important tool for combining the efforts of business, science and the state to implement the priority areas of modernization and technological development of the Russian economy. Currently, there are 34 industrial platforms in 13 of the most promising areas of scientific and technological development in Russia.

These self-organizing associations include more than 3,500 members - companies, scientific and educational organizations, development institutions.

Next, we will consider the rating of the level of digitalization of the Kursk region economy. In the all-Russian rating, the index of the Kursk region increased compared with other regions in 2018, and the region took 22nd place.

The main factors that affect the uneven development of digitalization in the Kursk region are: insufficient funding, a shortage of highly qualified personnel, the need to constantly create an information environment for the development of digital technologies [23].

\section{MAIN PART}

The main problems of digitalization of the Kursk region, for which state projects are created, are:

\section{Organization of modern broadband Internet access.}

2. The constantly increasing need for a unified information space in the field of organization of information interaction. Currently, the technology for collecting and analyzing information has not been developed.

3. Currently, there is an insufficiently developed infrastructure of the population's access to state and municipal websites of the authorities.

4. Lack of skills in the use of modern technologies not only among citizens, but also among civil servants.

5. Lack of federal support in the development of the regional digital system.

6. Organizational and technological difficulties that hinder electronic documents flow.

In connection with these problems, in 2019 the Committee of Digital Development and Communication of the Kursk region was approved, the main tasks of which are:

1. Development of regional informatization. 
2. Ensuring the introduction and widespread use of modern information, communication and innovative technologies.

3. Organization of the conversion of regional services into a regional form.

4. Information support and increasing the transparency of information about the activities of the Administration of the Kursk region.

5. Ensuring the provision of public services, as well as regional monitoring.

Within the framework of the national project "Digital Economy of the Russian Federation" in the Kursk region, work was being created to implement the project "Digital Public Administration". Activities for the implementation of this project in 2019-2024 should be:

1. Ensuring the provision of regional services and services provided by the authorities of the Kursk region.

2. It is necessary to organize the transfer of service delivery processes to a cloud digital platform.

3. Ensuring the unification of the activities of multifunctional centers based on state standards.

4. Creation of a digital platform for the rule-making process.

5. Use of a platform for interdepartmental interaction of data exchange, creation of a data management system in the state authorities of the Kursk region.

6. Ensuring access of citizens of the Kursk region to public and municipal services in the "one window" model based on the "Unified Portal of Public and Municipal Services" system.

7. Creation and use of "electronic passports" in the Kursk region.

8. Ensuring the application of the job search platform and personnel on the all-Russian database of vacancies "Work in Russia" [24].

In the Kursk region the preparation of the projects "Smart City" and "Safe City" is also continuing. The strategic goal is the implementation of a model of sustainable eco-oriented development, the development of a "green" economy, the solution of environmental problems to fully meet the needs of the population in the formation of an eco-friendly environment.

This project will be aimed at improving the quality of life, creating a technological and comfortable urban environment, increasing the quality of life of the population, increasing investment attractiveness, saving resource consumption. The plans present the development of technological solutions in the life of the population, namely: smart energy, advanced solutions in the field of urban population and infrastructure, a transparent system of housing and communal services.

The key goal of the project is to ensure the technological independence of the state, the possibility of commercializing domestic research and development, as well as accelerating the technological development of Russian companies and ensuring the competitiveness of their products and solutions in the global market.
The regional project "Digital Technologies" was created for projects of introduction of digital technologies in economic sectors. The expected results should be:

- development and implementation of "Road maps" for the development of promising "end-to-end" digital technologies;

- support for leading companies developing products for digitalization of the economy and social sphere;

- support for regional projects to transform priority sectors of the economy and social sphere [24].

List of end-to-end digital technologies: big data; new production technologies; industrial Internet; artificial intelligence; wireless technology; robotics and sensorics components; quantum technologies; distributed ledger systems; virtual and augmented reality technologies.

\section{CONCLUSION}

The digital economy is a new type of economic relations in all sectors of the world market. For its development, it is necessary to create an infrastructure, including hardware, software, telecommunications, etc., build new business models, scientific and social networks, build trust in the reliability and security of digital infrastructure, assess risks, increase the level of digital technology skills, train and retrain specialists. The prerequisites for the development of the digital economy in Russia include a high potential for training specialists in the digital economy, the availability of technological solutions to create an effective infrastructure.

The development of the digital economy is one of the priority industries in the development of the region, because the digital economy is ensured through the automation of all processes and data processing technologies. There are certain problems that hinder the development of the digital economy in the Kursk region. However, apart from the problems, you can also find prospects, such as federal and regional support, the creation and supervision of projects, which were described above. The implementation of such projects is a strategically important task, by which economic development will be ensured both at the regional and federal levels.

The digital sector is growing rapidly in the world. The number of users of the latest digital achievements is increasing every year. Digital technologies contribute to social and financial inclusion of the population and increase the availability, quality and convenience of receiving services in such important areas as medicine, education, municipal and public services, and culture.

The world's leading countries see the introduction of digital technologies as one of the main factors of innovative development and strengthening competitive advantages. Today Russia lags behind in the development and quality of communication networks, only develops strategies for creating its own digital market and remains an area with undiscovered potential. Russia lags behind the leading countries in the growth of the digital economy. The main problem with the growth of domestic innovative companies is the lack of investment.

It is obvious that the changes taking place in the world's economy are, on the one hand, a serious challenge, and, on the other hand, new opportunities for finding Russia's specialization in the global digital environment and forming 
directions for modernizing the traditional economy on this basis [25-27].

It should be noted that in recent years, the Russian regions have made some progress in the development of digital technologies at the level of households, enterprises and digital government.

However, the problems of uneven territorial development, bureaucratization of the process of introducing digital technologies in the regions and the lack of a clearly formulated legislative base in this field remain unresolved.

In order to develop the digital economy in the regions, it is necessary to organize training for regional managers in digital technologies, create an all-Russian rating of digital development of the regions and exchange best practices, coordinate the digitalization process in the regions at the federal level, and equalize the situation in the regions. The creation of new structures for the development of digitalization, horizontal and vertical cooperation between sectors of the economy, interaction between the state, research institutes based on universities and private enterprises will allow developing the digital economy in the regions.

\section{REFERENCES}

[1] A.A. Nikolenko, E.S. Belyaeva, O.V. Emelyanova, "Features of the market of innovative technologies and its role in the regional economy", Innovative economy: prospects for development and improvement, 2016, 7(17), pp. 238-242.

[2] N.A. Mashkina, A.P. Shaforost, "Introduction of digital technologies into the economy of the Russian Federation. Innovative economy: prospects for development and improvement, 2019, 7 (41), pp. 72-79.

[3] A.G. Bantyeva, N.A. Mashkina, "Digital economy in the modern world and in modern Russia: its significance and development. In the collection: Digital economy: problems and development prospects Collection of scientific articles of the Interregional scientific and practical conference", 2019, pp. 63-72.

[4] Nela Milošević, Marina Dobrota, Barjaktarovic Rakocevic, Sladjana, "Digital economy in Europe: Evaluation of countries' performances. Zbornik Radova Ekonomskog Fakultet au Rijeci”, 2018, 36, pp. 861880. DOI: $10.18045 /$ zbefri.2018.2.861

[5] T.S. Kolmykova, A.V. Zelenov, "New quality of human capital in the context of digital transformation of economic space", Economics and Management: Problems, Solutions, 2020, 4, pp. 4-8.

[6] T.S. Kolmykova, A.V. Zelenov, Research of trends in the development of the digital economy. In the collection: Institutions and mechanisms of innovative development: world experience and Russian practice, Collection of scientific articles of the 9th International Scientific and Practical Conference, 2019, pp. 186-189.

[7] I.G. Ershova, O.V. Belyaeva, A.S. Obukhova, "Assessment of financing the human capital of regions in the context of digitalization", Bulletin of the North Caucasus Federal University, 2020, 3 (78), pp. 14-24.

[8] I. Ershova, O. Belyaeva, A. Obukhova, "Investment in human capital education under the digital economy", Економічний часопис-XXI, 2019, 11-12, pp. 69-77. DOI: 10.21003/ea.V180-08

[9] Danila, Valko, "Digitalization of the Regional Socio-EcologicalEconomics Space of Russia”, Zhurnal Economicheskoj Teorii, 2019, 16, pp. 402-413. DOI: 10.31063/2073-6517/2019.16-3.9

[10] A. Gretchenko, "The Formation Of The Digital Economy In Russian Regions", 2020, pp. 430-436. DOI: 10.15405/epsbs.2020.03.62

[11] V.O. Moiseev, "Digital economy: problems and prospects", Electronic scientific journal "Vector of Economics", 2019, 11. URL: http://www. vectoreconomy.ru/images/publications/2019/11/innovationmanageme nt/Pavlova_Mo iseev.pdf. (accessed 10.11.2020).

[12] G. I. Abdrakhmanova, K. O. Vishnevsky, L. M. Gokhberg and others, "Indicators of the digital economy: 2020: statistical collection.Nat. issled", University Higher School of Economics. - M.: NRU HSE, 2020.
[13] Information agency "RosBusinessConsulting". URL: https://www.rbc.ru (accessed 10.11.2020)

[14] "Moscow School of Management". URL: https://finance.skolkovo.ru (accessed 10.11.2020)

[15] Official site "Government of the Russian Federation". URL: Access mode: http://government.ru (accessed 10.11.2020).

[16] Index "Digital Russia", The results of measuring the Digital Russia index by constituent entities of the Russian Federation in 2018. URL: https://finance.skolkovo.ru/downloads/documents/FinChair/Research _Reports/SKOLKOVO_Digital_Russia_Report_Full_2019-04_ru.pdf (accessed 10.11.2020).

[17] M.A. Vetrova, D.V. Ivanova, "Assessment of digital maturity and readiness for digital transformation of the regions of the Russian Federation", 2020, pp. 99-104.

[18] Lyudmila Georgievna Batrakova, "Development of the digital economy in the regions of Russia", Socio-political research, 2019, (1), pp. 51-64. DOI: 10.24411/2658-428X-2019-10338

[19] T.E. Rodina, A.N. Lysenko, "Digital technologies as a factor in the development of the regional economy", International Research Journal, 2020, (5-2 (95)), pp. 78-81.

[20] Matvey Sergeevich Oborin, "Digitalization as a factor in the transformation of the management of regional economic systems", Economy. Taxes. Pravo, 2020,13 (3), pp. 91-101.

[21] T.S. Kolmykova, "Introduction: regarding the future of the digital economy", Digital Future Economic Growth, Social Adaptation, and Technological Perspectives. Cep. "Lecture Notes in Networks and Systems", Cham, 2020, pp. 5-7.

[22] E. Kurushina, M. Petrov, " Digitalization of economy at the macroregion level”, Zhurnal Economicheskoj Teorii, 2020, 17, pp. 101-116. DOI: $10.31063 / 2073-6517 / 2020.17-1.8$.

[23] "Territorial body of the Federal State Statistics Service for the Kursk Region”. URL: https:// Federal State Statistics (accessed 10.11.2020).

[24] Official site "Administration of the Kursk region". URL: https://adm.rkursk.ru/ (accessed 18.11.2020).

[25] N. Mashkina, E. Yakimova, "Digital finance as a part of the world economy", Social science, education and human science, 2020, pp. 274-280.

[26] N.A. Mashkina, A.A. Mukovnina, "Digital finance as part of the global economy", CITISE, 2019, 5(22), pp. 324-334. DOI: 10.15350/24097616. 2019.5.29.

[27] N.A. Mashkina, V.V. Grishina, Digitalization of the Russian insurance market: problems and prospects. In the book: Scientific research: pedagogical, innovative-managerial and economic technologies (information, analysis, forecast), Monograph, Voronezh -Moscow, 2019 , pp. $163-169$. 